\title{
Key Factors for Sustainable Industrial Cities
}

\author{
Ingy M. El Barmelgy ${ }^{1} \&$ Motaz S. Aly ${ }^{2}$ \\ ${ }^{1}$ Architecture Department, Faculty of Engineering, Cairo University, Egypt \\ ${ }^{2}$ General Organizations for Physical Planning, Ministry of Housing, Cairo, Egypt \\ Correspondence: Ingy M. El Barmelgy, 12 hanora tower, El barmelgy street of Al bahr El Azam street, Giza, \\ Egypt. Tel: 2-012-2234-5178. E-mail: i_barmelgy@yahoo.com
}

Received: October 6, 2016 Accepted: October 18, 2016 Online Published: February 3, 2017

doi:10.5539/jsd.v10n1p41 URL: http://dx.doi.org/10.5539/jsd.v10n1p41

\begin{abstract}
The industry is one of the main pillars of a strong economic city. Unfortunately, third world countries' industrial cities face environmental threats to the point that sustainable environments are considered a luxury (Pugh, C, 2013). According to a report issued by the Ministry of Agriculture and Land Reclamation in 2015 Egypt lost approximately 8618 acres of the finest farmland in the Delta and the Nile Valley as a result of urban sprawl on farmland to take advantage of employment opportunities and services in cities (Ministry of Agriculture land protection and land reclamation, 2015). The paper attempts to monitor different cases in the Egyptian context, trying to conclude the effective factors for their environmental and urban form as a result of industrial use. The Aim is to conclude key factors for sustainable industrial cities. The paper's results are based on a designed questionnaire that is analysed using SPSS. The questionnaire is completed with the help of experts and executives in order to specify the main factors in the sustainable urban form regarding industrial cities. It is followed by cluster analysis to determine the positive or negative effects of each element in relation to the rest of the elements concluding the most effective factor affecting the environment in every group as a tool to help the urban planning decision makers (environmental - urban - economic and social).
\end{abstract}

Keywords: environment, industrial cities, pollution, sustainable form, sustainability, urban planning

\section{Introduction}

This paper attempts to solve the dilemma between sustainable forms and industrial bases through specifying the main factors clearly as a tool for urban planners. There are several factors affecting the urban environment, especially within the industrial cities where the industrial use causes a lot of environmental threats. These threats include dumping industrial sewage into waterways, air pollution with toxic gases and hazardous waste for some industries, and negative impacts on surrounding residential areas and the urban form generally (Tan Yigitcanlar\& M. Kamruzaman, 2015).

The main objective of this paper is to determine the key factors affecting the urban environment. For practice, to determine these factors, a theoretical approach is adopted to form a clear review of the factors through studying Industrial Development Authority standards, Millennium Development Goals of the United Nations (United Nations [UN], 2013), Studies and indicator theory. This is followed by an analysis of the EEAA standards and international cities such as the Joshua city in China (Institute of design and urban planning (Tongji), 2014), Skikda city in Algeria (Institute for Urban and management techniques, 2011), the city of Glasgow in the UK (Glasgow city plan \& vision, 2014), and the policies of some countries such as France, England and China (World Bank, 2014).

The finalized factors are then revised and matched with the analysis of six Egyptian cities; Kafr El-Dawar (Ministry of Housing (MOH, 2013) - Kafr El Zayat (MOH, 2014) - Hawamdeya (MOH, 2014) - Mahalla Al Kubra (MOH, 2013) - Talkha (MOH, 2012) - Deshna (MOH, 2015).

After reviewing and studying different sources, the paper will identify these factors with respect to developing countries. To arrange these factors, a designed questionnaire for experts and executives is adopted, afterwards, the most and least influential factor in the environment as a result of the presence of the industry is identified by using the statistical analysis program (SPSS) as well as the most influential factor in each group (environmental, urban, economic and social). 


\section{Overview}

All throughout Egypt, the cultural heritage factor is an important factor. Damietta has been famous for the wood industries (furniture - Arabesque - fishing boats) since the Ottoman conquest of Egypt, while Assiut is famous for spinning wool, carpets and Kilims since ancient times. This cultural heritage acts as a great comparative advantage in the authenticity either in small industries with similar or more sophisticated to urban communities with greater history and their neighbouring communities. This must be taken into account when proposing a small rural industry, as it should have historical roots in the city to keep pace with the current market needs (Allam, A, Khalid, 1995).

\subsection{Overview of Egypt's Situation as Developing Country}

Egyptian cities are suffering from the random spread of residential areas where these areas are held in the absence of both urban planning and the protection of agricultural land. Such areas may exist as part of the city or on the edges of the agricultural land; they lack proper planning and suffer from facilities and services deficiency. Mostly, they suffer from environmental pollution in addition to the low level of social, economic and environmental life (General Organization for Physical Planning (GOPP), 2014).

One of the main causes of the spread of these areas is the presence of attractive industries for employment, leading to endemic workers on the outskirts of the city.

This problem is common in cities that have an agricultural boundary and include concentrated labour-intensive industries in them such as the textile industry, which exists in cities such as: Kafr El Dawar, Kafr El Zayat, Hawamdeya, and Mahalla al-Kubra. These cities rely on a large number of employees where most of them are from the city and the neighbouring villages. It is some of those employees that decided to move next to their work, creating these expanding residential areas (Aly, M Sayed, 2014).

Also, this problem appears in coastal cities such as Port Said and Suez, where the industries exist and as a result of increased population growth rates, lack of an appropriate residential balance exists due to unplanned growth (Papa, Rocco, 2016).

The presence of industrial use in these cities has a significant impact on their population densities compared to those of the rest of the cities as illustrated (tab.1) (Source author using data from, Egypt Census Report (ECR) and Egyptian Urban Observatory (EUO), 2016). Shaded cities are the cities that have based industries where increased population density of 100 people / acre and up to 160 people / acre like Girga City as the cities that do not have a based industrial of the average population density of 70 people / acre.

Table 1. Illustrate high densities in industrial cities compared to other cities

\begin{tabular}{ccc}
\hline GOVERNMENT & CITY & Density Per/acre \\
\hline GHARBYA & Kafr El-Dawar & 120 \\
GHARBYA & Kafr El-Zayat & 72 \\
GIZA & Hawamdia & 113 \\
GHARBYA & Mahalla al-Kubra & 90 \\
PORT SAID & Port Said & 21 \\
SUEZ & Suez & 20 \\
DAQAHLYA & Talkha & 119 \\
QENA & Deshna & 75 \\
SOHAG & Girga & 160 \\
MINYA & Abo Qorqas & 30 \\
DAMYAT & Faraskor & 112 \\
SHARQYA & Belbis & 92 \\
GIZA & Badrashen & 35 \\
BEHERA & Edko & 88 \\
MINYA & Maghagha & 143
\end{tabular}




$\begin{array}{ccc}\text { MONOFYA } & \text { Berket Al-Sabeaa } & 69 \\ \text { DAQAHLYA } & \text { Bani Ebeid } & 82 \\ \text { DAQAHLYA } & \text { Nabaruh } & 99 \\ \text { SHARQYA } & \text { Faqus } & 71 \\ \text { SHARQYA } & \text { Kafr Saqr } & 111 \\ \text { QALYOBIA } & \text { Tokh } & 124 \\ \text { QALYOBIA } & \text { Kafr Shokr } & 87 \\ \text { QALYOBIA } & \text { Qaha } & 155 \\ \text { KAFR AL SHEKH } & \text { Desok } & 136 \\ \text { GIZA } & \text { El- Ayyat } & 89\end{array}$

\subsection{Factors Affecting the Physical Growth of the Egyptian Cities}

Urban extensions of cities are a real dilemma for land management as many factors affect the urban extension; these factors change depending natural factors, social factors, political, administrative and economic, etc.

Yet, the main factor which encourages the extension of the Egyptian cities is the economic factor. This is illustrated (tab. 2) (Source: author using data from, ECR, 2016 and EUO, 2015). The shaded rows show cities with an industrial base. The urban cluster of cities with an industrial base increased compared to those without an industrial base and this is a result of increased demand for residential and service land in these cities as a result of labour mobility for housing. For example, Kafr Al-Dawar city has an area of 2190 acres, Hawamdeya 1223.64 acres, and Mahalla Al-kobra 1291 acres (Source author using data from (GOPP, 2015), while the rest of the cities in the same category have an average area of about 1,000 acres. This confirms the effect of the presence of industries on the urban cluster of cities (ECR, 2016).

Table 2. Shows the population and areas in some industrial cities in Egypt

\begin{tabular}{ccc}
\hline CITY & Area (Acre) & Inhabitants \\
\hline Kafr El-Dawar & 2190.7 & 2016 \\
Kafr El-Zayat & 1193 & 85,313 \\
Hawamdeya & 1223.64 & 137,722 \\
Mahalla al-Kobra & 1291 & 115,777 \\
Port Said & 32000 & 672,072 \\
Suez & 31621 & 629,616 \\
Talkha & 798 & 94,991 \\
Deshna & 877 & 65,459 \\
Girga & 706 & 112,920 \\
Abo Qorqas & 580 & 17,354 \\
Faraskor & 350 & 39,257 \\
Belbis & 1820 & 169,036 \\
Badrasheen & 2254 & 78,679 \\
Edko & 1366.7 & 119,952 \\
Maghaghah & 530 & 75,700 \\
EL-Hamam & 2582 & 72,393 \\
Berket El- Sabaa & 581 & 40,089 \\
Belqas & 1401 & 115,117
\end{tabular}




\begin{tabular}{ccc} 
Dekernes & 1214 & 81,570 \\
Baniebed & 441 & 36,065 \\
Nabaroo & 463 & 45,652 \\
Faqos & 1310 & 93,357 \\
Kafr Saqr & 334 & 37,109 \\
Tokh & 406 & 50,351 \\
Kafr Shokr & 326.9 & 28,300 \\
Qaha & 209.5 & 32,381 \\
Desok & 971 & 132,272 \\
EL-Ayyat & 467.22 & 41,528 \\
\hline
\end{tabular}

It has an impact on attracting construction in the direction of economic activities due to the availability of work and the low prices of residential units.

This advantage for the working group seeking residence is considered as a component of attracting extensions in the desired directions by establishing factories, economic projects and other activities near the areas in order to drive them away from the random extensions of cities. When industries appear in one of the cities, margins grow along with the residential suburbs industry associated with it, even if it was outside the maximum chamber taking over agricultural lands (H, Al Omar et al., 2002).

The ratio of the industrial area to the residential cluster in the cities which have an industrial base is too high in cities like Kafr El-Dawar, Talkha or Deshna (Fig.1) (author). It's more than the residential area, which makes us wonder if it's a residential city with industries in its margins or an industrial city with labour camps. Generally, the industrial ratio is too high in all cities which give an indicator about the impact of the industry on the environment, infrastructure, urban form, etc. (GOPP, 2011).

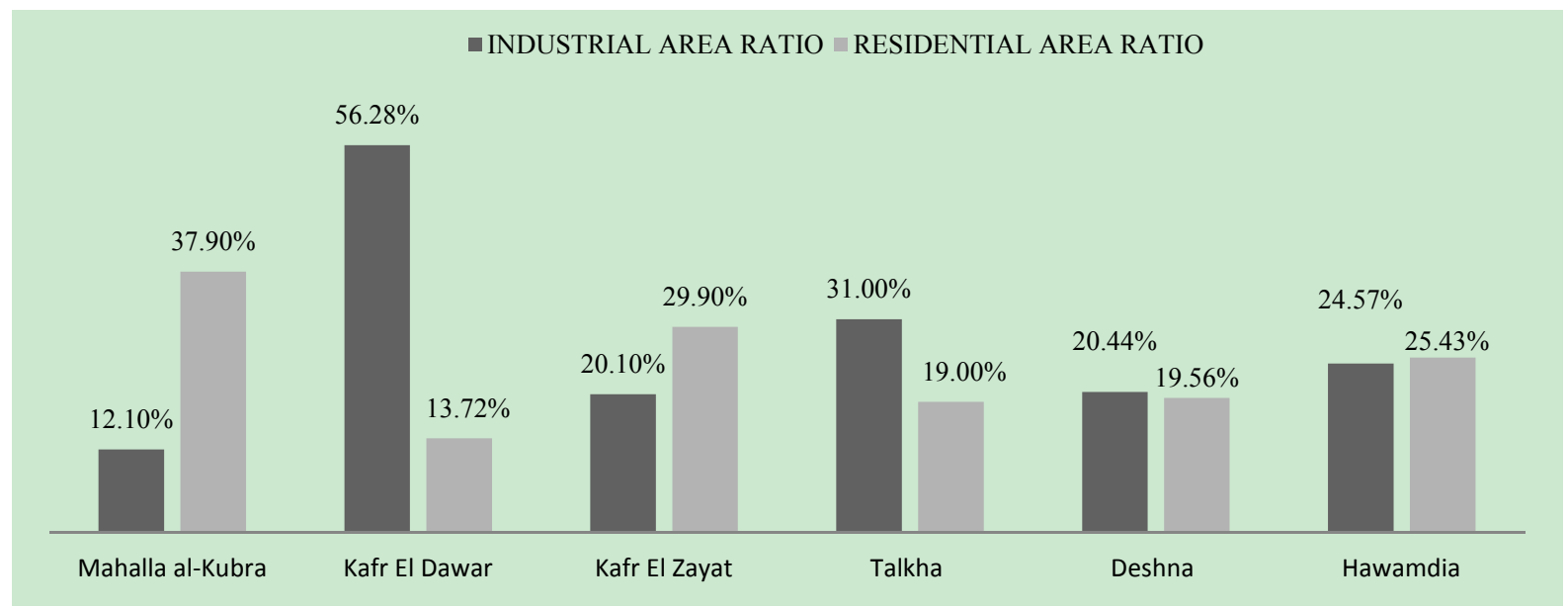

Figure1. Ratio industrial area to residential area in case studies

\subsection{The Role of Governmental Organizations in Redrawing the Egyptian Industry Map (Administrative Bodies Responsibilities and Interrelations for Egyptian Industrial Map)}

The placement of industrial development is considered the most economical factor guiding the city's urban form, which is the real issue to be discussed. In Egypt, the Industrial Development Authority is responsible for drawing the Egyptian industrial map where its role varies between the preparation of plans and mechanisms necessary to make industrial areas work and the establishment of industrial complexes as shown (Fig.1) (Source: author using data from, Environment Law). To support sustainable development plans complexes of the specialized agencies should target, optimizing the use of available resources, and increasing the added value of the industrial product should be the criteria in the proposed.

The General Authority for Urban Planning is the state body responsible for planning policy, urban development, 
sustainable development, and preparing plans and programs for these developments at the national and regional levels, as well as the preparation of the strategic plans for Egyptian cities. (GOPP, 2011)

EEAA refers to the Egyptian Environmental Affairs Agency, which is responsible for any environmental impact for any project. It has a law that states that the environmental impact of certain establishments or projects must be evaluated before any construction works are initiated or a license is issued by the competent administrative authority or licensing authority.

The numbers of projects subject to this provision are many and will form a heavy burden to administrative authorities and the EEAA. A flexible system for the management of EIA projects has therefore been developed in order to use limited economic and technical resources in the best possible way.

The system encompasses a flexible screening system and projects are classified into three groups, or classes, reflecting the different levels of environmental impact assessment according to the severity of possible environmental impacts (Egyptian environmental affairs agency (EEAA) - Environment Law).

The "A" list projects for establishments/projects with minor environmental impact.

The "B" list projects for establishments/projects which may result in substantial environmental impact.

The "C" list projects for establishments/projects which require complete EIA due to their potential.

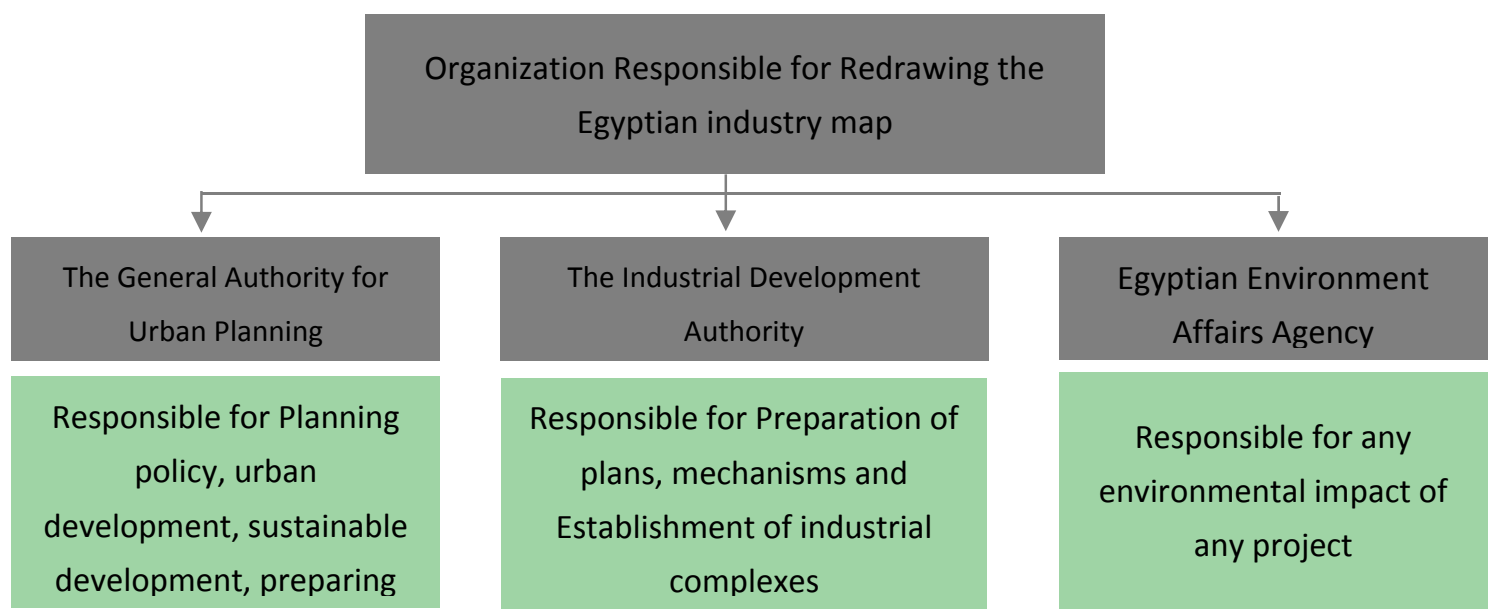

Figure 2. Diagrams shows the Administrative bodies responsibilities and interrelations for Egyptian industrial map

\section{Empirical Study Methodology}

The research's main aim is to conclude the key factors for sustainable industrial cities. To achieve this aim, this part of the study is met by concluding these factors. The factors that affect the urban environment were finalized from different sources such as the Industrial Development Authority standards, the Millennium Development Goals of the United Nations, Studies and indicators theory, EEAA standards (EEAA, 2014), Egyptian cities indicator, analysis of a number of international cities such as (Joshua city in China - Skikda city in Algeria - the city of Glasgow in UK), and the analysis of the policies of some countries, such as France, England and China, this part of the study consists of three steps. Step 1: after reviewing different sources the paper identifies these factors. Step 2: categorizing the factors (setting main factors' checklist). Finally, step 3; a designed questionnaire for experts and executives to arrange these factors, then the use of statistical analysis program (SPSS) to determine the most and the least influential factor. (Yigitcanlar, T. Dur\& F. Dizdaroglu, D, 2015) Next, arranging them in relation to the environment as a result of the presence of the industry, followed by stating the most influential factor in each group (environmental - urban - economic and social), and the positive or negative effects of one factor on the rest.

The statistical analysis was carried out using the SPSS (Statistical Package for Social Sciences) program, which can be precisely illustrated within three main steps. Step 1: This part forms a general view of the elements that affect the urban environment in industrial cities to achieve this quick review for reports, manuals, international and national projects. In addition, to identify the most influential factor in the urban environment based on the number of standards and foundations that are derived from the opinions of specialized and theoretical studies and 
analysis of local and global experiences.

Step 2: Categorizing the factors (setting main factors' checklist). Factors are classified into three sources; environment, urban, economic and social factors. After identifying the main sources, we extract the factors affecting the physical environment as a result of the establishment of industrial activity. We then start to identify and prioritize these factors strictly in accordance with origin as shown (Tab.3) (Source author using data from, EEAA, 2013). In spite of having a lot of standards for establishing industrial activity, the negative impact of these activities on the physical environment is still present, in particular, in cities with an agricultural background.

Table 3. Final elements affecting the urban environment categorized by source

\begin{tabular}{|c|c|c|c|c|c|c|}
\hline $\begin{array}{c}\text { Studies and } \\
\text { other indicators }\end{array}$ & $\begin{array}{c}\text { Industrial } \\
\text { Development } \\
\text { Authority standards }\end{array}$ & EEAA standards & $\begin{array}{c}\text { The Millennium } \\
\text { Development } \\
\text { Goals }\end{array}$ & $\begin{array}{l}\text { Analysis of local } \\
\text { and global cities }\end{array}$ & $\begin{array}{l}\text { Theoretical } \\
\text { framework }\end{array}$ & \\
\hline $\begin{array}{l}\text { Slums area of } \\
\text { the total mass }\end{array}$ & $\begin{array}{l}\text { Increase the } \\
\text { distance between the } \\
\text { industrial zone } \\
\text { (inside the city) and } \\
\text { the nearest road } \\
\text { about } 7 \mathrm{~km} \text { regional }\end{array}$ & $\begin{array}{l}\text { The high proportion } \\
\text { of contaminated } \\
\text { output of these } \\
\text { industries within the } \\
\text { city }\end{array}$ & $\begin{array}{c}\text { Eradicating } \\
\text { extreme poverty } \\
\text { (relying on } \\
\text { employment) }\end{array}$ & $\begin{array}{l}\text { The lack of } \\
\text { Residential units } \\
\text { allows Urban } \\
\text { growth without } \\
\text { encroaching on } \\
\text { farmland }\end{array}$ & $\begin{array}{l}\text { The absence of a } \\
\text { regional industrial } \\
\text { zone in the } \\
\text { distance, not far } \\
\text { from the city of } \\
\text { more than } 40 \mathrm{~km}\end{array}$ & \\
\hline $\begin{array}{l}\text { The presence of } \\
\text { a regional } \\
\text { industrial zone }\end{array}$ & $\begin{array}{l}\text { The type of } \\
\text { industrial activity } \\
\text { (in terms of the } \\
\text { nature of the } \\
\text { activity) }\end{array}$ & $\begin{array}{l}\text { The intensity of the } \\
\text { electrical energy } \\
\text { consumption }\end{array}$ & $\begin{array}{l}\text { Achieving } \\
\text { universal primary } \\
\text { education (not to } \\
\text { rely on child } \\
\text { labor) }\end{array}$ & $\begin{array}{c}\text { The proportion of } \\
\text { buildings related to } \\
\text { network } \\
\text { infrastructure }\end{array}$ & $\begin{array}{l}\text { Factory Site } \\
\text { according to } \\
\text { sewage water }\end{array}$ & \\
\hline $\begin{array}{c}\text { The average } \\
\text { annual increase } \\
\text { for the Urban } \\
\text { Mass }\end{array}$ & $\begin{array}{c}\text { The type of } \\
\text { industrial activity } \\
\text { (in terms of } \\
\text { employment) }\end{array}$ & $\begin{array}{l}\text { The type of industrial } \\
\text { activity } \\
\text { (labour-intensive - } \\
\text { capital-intensive) }\end{array}$ & $\begin{array}{l}\text { Promote gender } \\
\text { equality and } \\
\text { empower women } \\
\text { (women allowed } \\
\text { to run) }\end{array}$ & $\begin{array}{l}\text { The high } \\
\text { proportion of } \\
\text { industrial use in } \\
\text { the city of about } \\
10 \% \text { of the total } \\
\text { area of the block }\end{array}$ & $\begin{array}{l}\text { Increase the } \\
\text { distance between } \\
\text { the industrial zone } \\
\text { (inside the city) } \\
\text { and the areas of } \\
\text { marketing for } 25 \\
\mathrm{~km}\end{array}$ & \\
\hline $\begin{array}{l}\text { High rates of } \\
\text { immigration to } \\
\text { the city }\end{array}$ & & $\begin{array}{l}\text { Environmental } \\
\text { effects of the plants } \\
\text { (a type of pollution) }\end{array}$ & $\begin{array}{l}\text { The presence of } \\
\text { flat growth } \\
\text { without urban } \\
\text { encroachment on } \\
\text { farmland }\end{array}$ & $\begin{array}{l}\text { Adoption of the } \\
\text { economic structure } \\
\text { of employment in } \\
\text { the city on } \\
\text { industrial activity }\end{array}$ & $\begin{array}{l}\text { Increase the } \\
\text { distance between } \\
\text { the industrial zone } \\
\text { (inside the city) } \\
\text { and manpower for } \\
25 \mathrm{~km}\end{array}$ & \\
\hline \multirow[t]{2}{*}{$\begin{array}{l}\text { The rate of } \\
\text { overcrowding }\end{array}$} & & $\begin{array}{c}\text { Industry } \\
\text { Classification, } \\
\text { according to EEAA }\end{array}$ & $\begin{array}{l}\text { Ensure that the } \\
\text { reasons for the } \\
\text { survival of the } \\
\text { environment }\end{array}$ & $\begin{array}{l}\text { The proportion of } \\
\text { poor and rundown } \\
\text { buildings }\end{array}$ & $\begin{array}{l}\text { The presence of } \\
\text { agricultural } \\
\text { hinterland of the } \\
\text { city }\end{array}$ & \\
\hline & & & & $\begin{array}{l}\text { Reduction of child } \\
\text { mortality and } \\
\text { disease control }\end{array}$ & $\begin{array}{l}\text { The presence of } \\
\text { traffic problems }\end{array}$ & \\
\hline
\end{tabular}


Step 3: To determine the extent of the importance of these elements and the relative weights, we design a questionnaire with two experts in the field of urban planning and executives in the governments. Afterwards, we merge them to discover the final results and final elements affecting the urban environment and the environmental situation in the cities as a result of the factory's location. About 50 questionnaires from executives, excluded 6 forms of analysis (final number 44), and filled 30 questionnaire by specialists, excluded 1 form of analysis (final number 29), on the form to reach the final count of the forms of executives and experts. Overall, we collected 73 questionnaires as this is the number of forms needed to validate the statistical tests performed through this research. Subsequently, we analysed them using the SPSS program to get the final result which is:

- Identifying the factors with the most negative effect on the urban environment.

- Identifying the most influential element in each group (urban - economic and social - environmental)

- Determining the positive or negative effect of an element on the rest of the elements.

\section{Discussion of the Findings}

4.1 Final Results of the Elements Affecting the Urban Environment of Cities According to the Opinion of Experts and Executives

The element with the most negative impact on the urban environment as a result of the factor's location is the presence of the industrial zones on the water source. That has achieved the highest percentage of 13\% (Fig.3) (author), followed by an arrangement in the high proportion of contaminated output followed by an absence of urban flat that allows growth. The achievement of the Millennium Development Goals of the United Nations has a less negative influence on the urban environment as a result of the factor's location. This has achieved the lowest percentage of $1 \%$, in order for the component to increase the distance between the industrial area and the areas of marketing for $25 \mathrm{~K}$ followed by an increase in the distance between the industrial areas and manpower about $25 \mathrm{~km}$. 


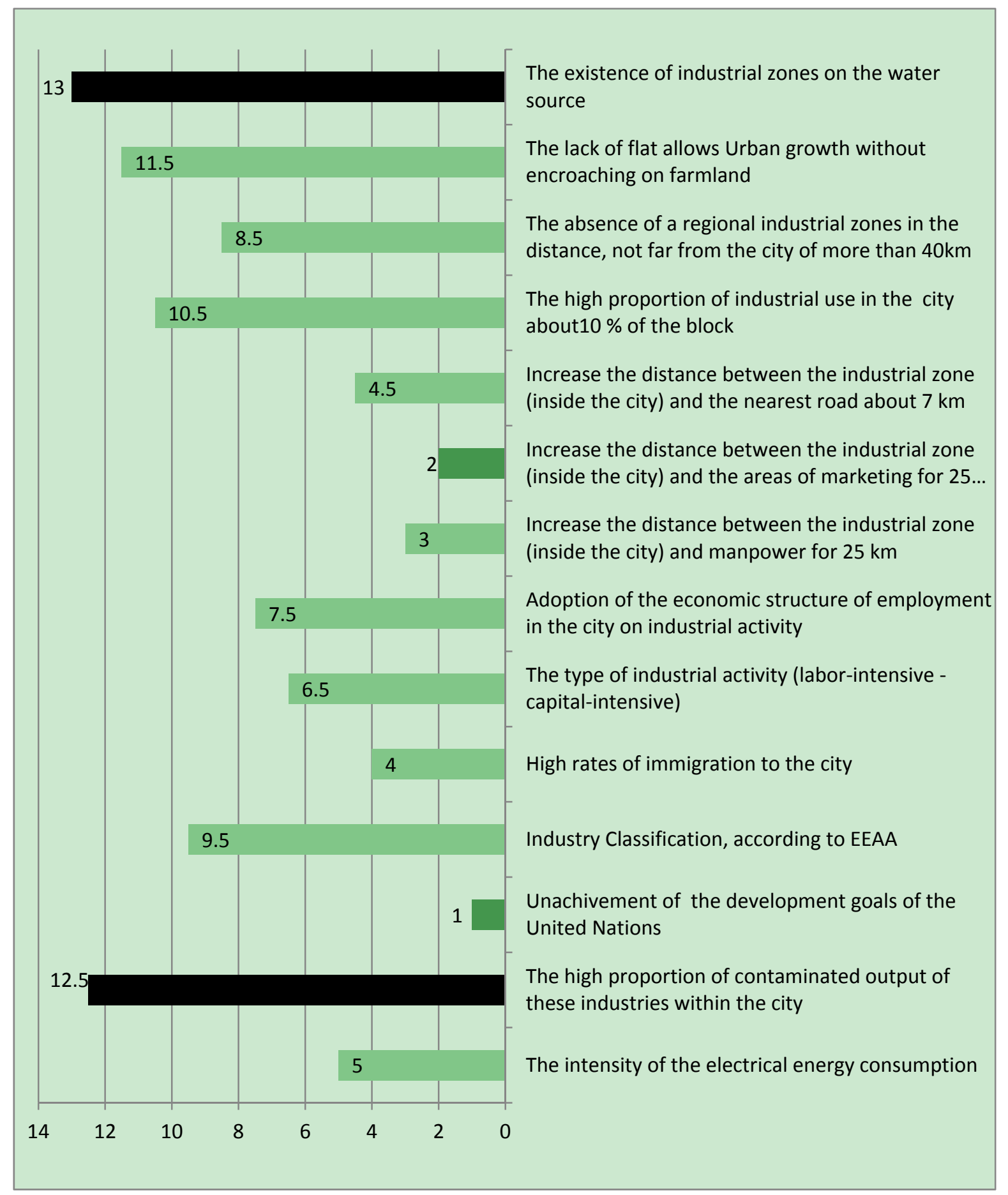

Figure 3. Final results of the elements affecting the urban environment of cities

4.2 The Final Ranking of the Importance of the Elements That Negatively Affect the Urban Environment in Cities According to the Opinion of the Executives and Experts

The existence of the industrial zones on the water source is the most negative element on the urban environment in the city according to the opinion of the executives and experts then the high proportion of the contaminated output of these industries within the city, as shown (Tab.4) (author). 
Table 4. The final ranking of the importance of the elements that negatively affect the urban environment in cities

\begin{tabular}{|c|c|c|c|c|c|}
\hline $\begin{array}{l}\text { Weight } \\
\text { Relative }\end{array}$ & $\begin{array}{l}\text { Final } \\
\text { Arrangement }\end{array}$ & $\begin{array}{l}\text { Absolute } \\
\text { Questionnaire }\end{array}$ & $\begin{array}{l}\text { According to the } \\
\text { opinion of and } \\
\text { executives }\end{array}$ & $\begin{array}{l}\text { According to the } \\
\text { opinion of } \\
\text { experts }\end{array}$ & Element \\
\hline$\%$ & Arr. & mean & mean & mean & \\
\hline $13 \%$ & 1 & 5.0909 & 2.0909 & 3.0000 & $\begin{array}{l}\text { The existence of industrial zones on the } \\
\text { water source }\end{array}$ \\
\hline $11 \%$ & 3 & 10.6818 & 4.6818 & 6.0000 & $\begin{array}{l}\text { The lack of flat allows Urban growth } \\
\text { without encroaching on farmland }\end{array}$ \\
\hline $9 \%$ & 6 & 14.0315 & 6.9545 & 7.0769 & $\begin{array}{l}\text { The absence of a regional industrial zone in } \\
\text { the distance, not far from the city of more } \\
\text { than } 40 \mathrm{~km}\end{array}$ \\
\hline $10 \%$ & 4 & 11.0070 & 6.5455 & 4.4615 & $\begin{array}{l}\text { The high proportion of industrial use in the } \\
\text { city about } 10 \% \text { of the total area of the block }\end{array}$ \\
\hline $5 \%$ & 10 & 17.8636 & 8.8636 & 9.0000 & $\begin{array}{l}\text { Increase the distance between the industrial } \\
\text { zone (inside the city) and the nearest road } \\
\text { about } 7 \mathrm{~km} \text { regional }\end{array}$ \\
\hline $2 \%$ & 13 & 18.5000 & 8.5000 & 10.0000 & $\begin{array}{l}\text { Increase the distance between the industrial } \\
\text { zone (inside the city) and the areas of } \\
\text { marketing for } 25 \mathrm{~km}\end{array}$ \\
\hline $3 \%$ & 12 & 18.1783 & 8.4091 & 9.7692 & $\begin{array}{l}\text { Increase the distance between the industrial } \\
\text { zone (inside the city) and manpower for } 25 \\
\mathrm{~km}\end{array}$ \\
\hline $8 \%$ & 7 & 16.7483 & 9.3636 & 7.3846 & $\begin{array}{l}\text { Adoption of the economic structure of } \\
\text { employment in the city on industrial } \\
\text { activity }\end{array}$ \\
\hline $7 \%$ & 8 & 16.8112 & 8.2727 & 8.5385 & $\begin{array}{l}\text { The type of industrial activity (labour - } \\
\text { intensive - capital - intensive) }\end{array}$ \\
\hline $4 \%$ & 11 & 18.1364 & 9.1364 & 9.0000 & High rates of immigration to the city \\
\hline $10 \%$ & 5 & 13.2448 & 6.0909 & 7.1538 & Industry Classification, according to EEAA \\
\hline $1 \%$ & 14 & 21.8881 & 11.2727 & 10.6154 & $\begin{array}{l}\text { Non-achievement of the development goals } \\
\text { of the United Nations }\end{array}$ \\
\hline $12 \%$ & 2 & 7.6993 & 4.5455 & 3.1538 & $\begin{array}{l}\text { The high proportion of contaminated output } \\
\text { of these industries within the city }\end{array}$ \\
\hline $6 \%$ & 9 & 17.4161 & 8.9545 & 8.4615 & $\begin{array}{l}\text { The intensity of the electrical energy } \\
\text { consumption }\end{array}$ \\
\hline 100 & & 207.297 & 103.6818 & 103.615 & sum \\
\hline
\end{tabular}

\subsection{Identifying the Most Influential Element in Each Group (Urban-Economic-Social and Environmental)}

The items affecting the physical and environmental conditions are categorized according to the groups to which they belong (environmental - urban - economics -etc.). 
The most influential element in the urban characteristics is the presence of the industrial zones on the water source, while the least influential element in the urban characteristics is increasing the distance between the industrial area and the marketing areas for the $25 \mathrm{~km}^{2}$ as shown (Tab.5) (author).

The most influential element in the economic and social characteristics is an industry classification according to the EEAA and the least influential element is the element of high rates of immigration to the city.

The most influential element in the environmental characteristics is a high proportion of contaminated output and the least influential element is the failure to achieve the Millennium Development Goals of the United Nations.

Table 5. Categorized the items affecting the physical and environmental condition

\begin{tabular}{|c|c|c|}
\hline Arr. & Element & Group \\
\hline 1 & The existence of industrial zones on the water source & \multirow{7}{*}{$\underset{巳}{\overparen{\Xi}}$} \\
\hline 2 & The lack of flat allows Urban growth without encroaching on farmland & \\
\hline 4 & The absence of a regional industrial zone in the distance, not far from the city of more than $40 \mathrm{~km}$ & \\
\hline 3 & The high proportion of industrial use in the city about $10 \%$ of the total area of the block & \\
\hline 5 & $\begin{array}{c}\text { Increase the distance between the industrial zone (inside the city) and the nearest road about } 7 \mathrm{~km} \\
\text { regional }\end{array}$ & \\
\hline 7 & Increase the distance between the industrial zone (inside the city) and the areas of marketing for $25 \mathrm{~km}$ & \\
\hline 6 & Increase the distance between the industrial zone (inside the city) and manpower for $25 \mathrm{~km}$ & \\
\hline 4 & High rates of immigration to the city & \multirow{4}{*}{ 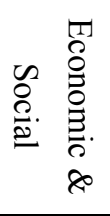 } \\
\hline 2 & Adoption of the economic structure of employment in the city on industrial activity & \\
\hline 3 & The type of industrial activity (labor-intensive - capital-intensive) & \\
\hline 1 & Industry Classification, according to EEAA & \\
\hline 3 & Non achievement of the development goals of the United Nations & \multirow{3}{*}{ 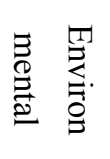 } \\
\hline 1 & The high proportion of contaminated output of these industries within the city & \\
\hline 2 & The intensity of the electrical energy consumption & \\
\hline
\end{tabular}

\subsection{Determine the Positive and Negative Effects of an Element on the Rest of the Elements}

\subsubsection{First Study: The Effect of the Presence of an Industrial Zone on the Water Source}

Given the effect of the presence of the industrial zones on the water source to extrusive effect where a high proportion of contaminated output increases and the absence of flat growth in most cities are achieved whenever there are factories on the water source.

On the contrary, the city doesn't achieve the development goals whenever there are factories on the water source. 
The influnce of existence of industrial zones on the water source

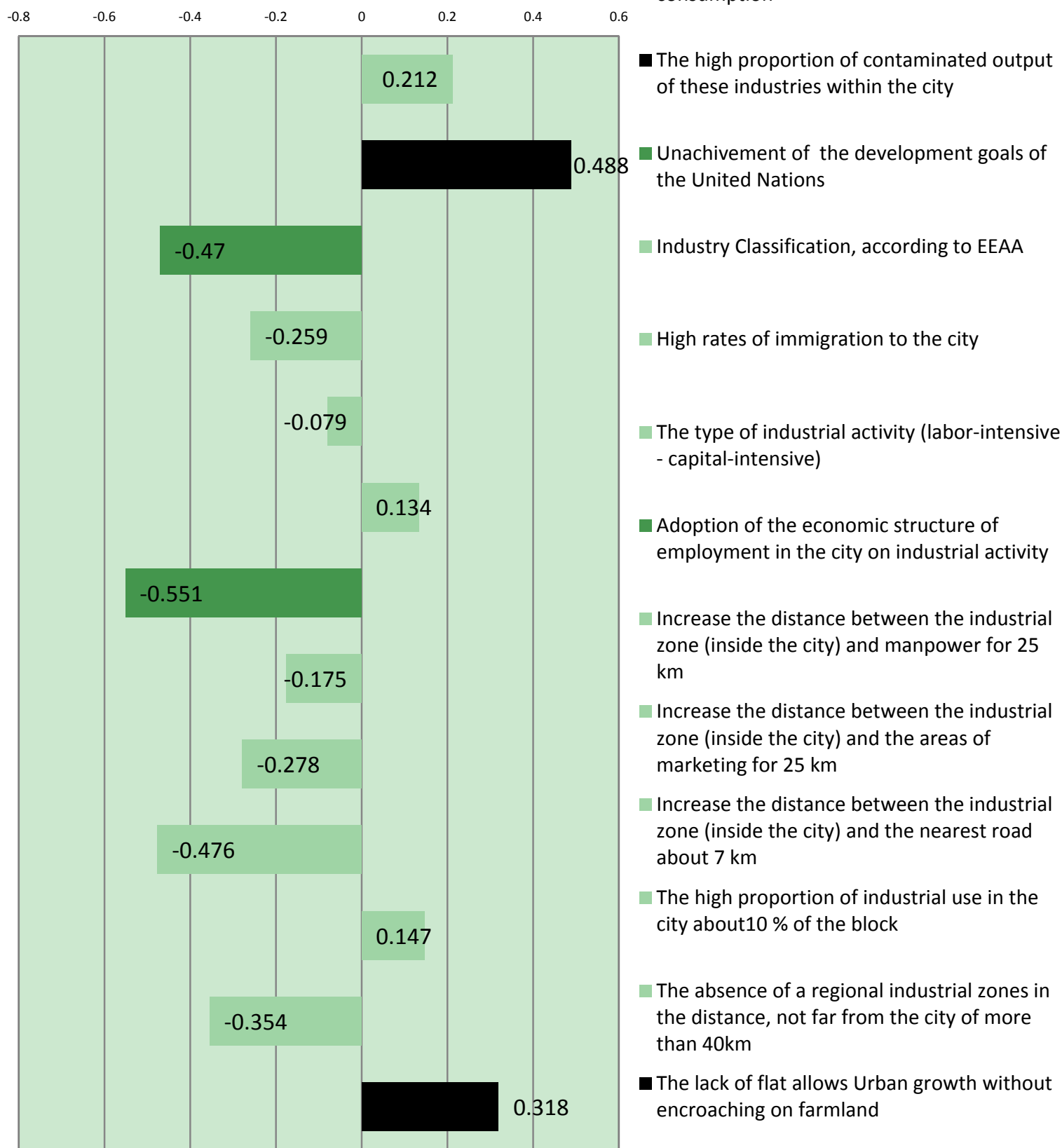

Figure 4. Ratios of the effective elements in the industrial zones

\subsubsection{Second Study: The Effect of the High Proportion of Contaminated Outputs}

Divided the effect of the high proportion of output to the impact of contaminated extrusive were high-output ratio industries always in the category of polluted black list classified according to the head of Environmental Affairs Industries also be energy-intensive. On the contrary, the city's economic structure doesn't depend on the industry or industrial activity; they are capital-intensive industries. 
The influnce of existence of the high proportion of contaminated outputs

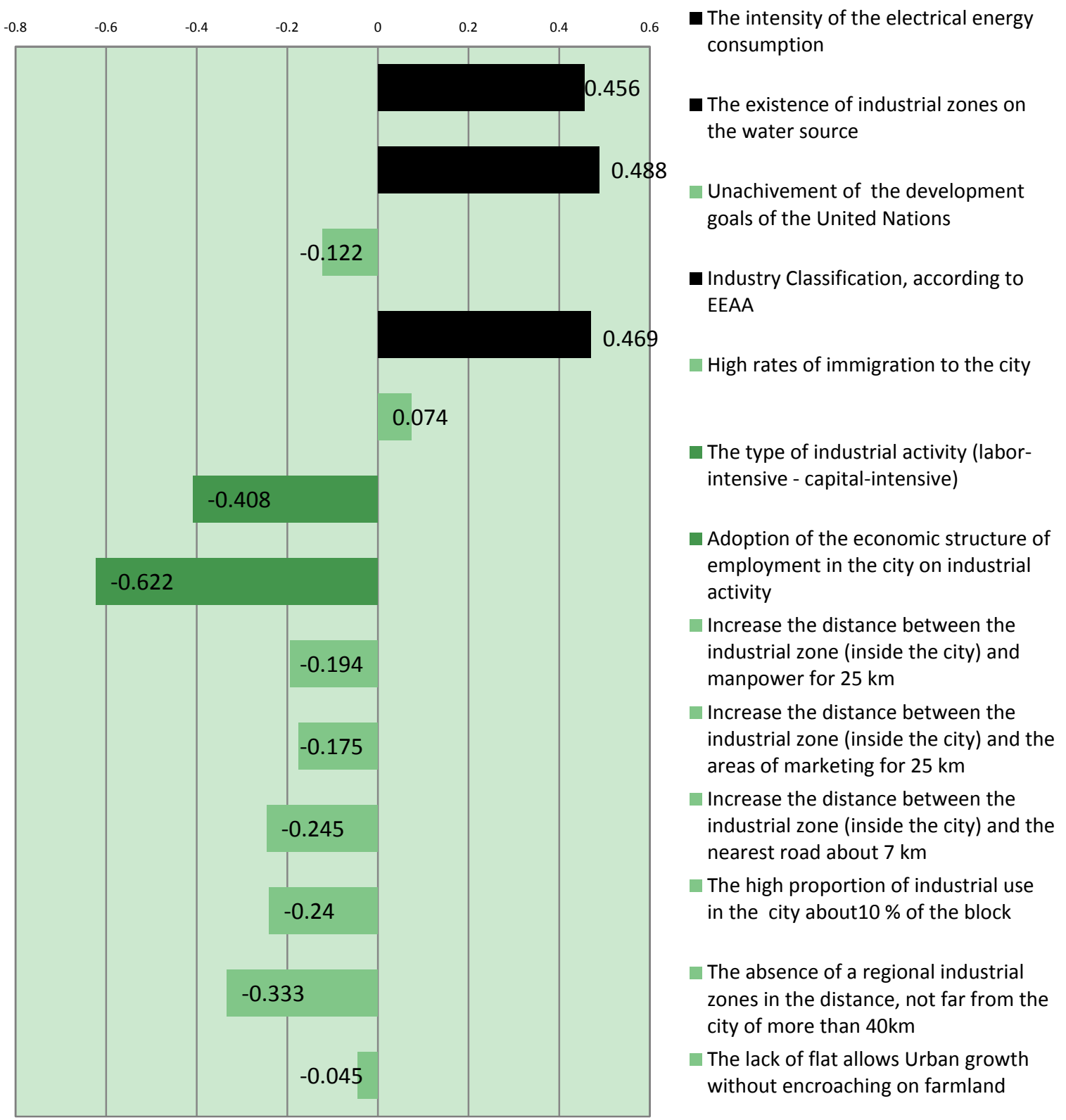

Figure 5. Ratio of the impact of rising output of polluting industries

\section{Conclusion and Recommendations}

From the analytical side, there is a need for entrances and various policies to address the problem of the industries' endemic within urban areas of cities where these industries cause deterioration of the physical environment. The characteristics of these cities are different and we could not apply a consistent policy of all situations, but we must classify cities into categories and make a special policy for each category (Ilaria \& Flavio, 2016).

Therefore, we must stand on the most important factors influencing the environmental and physical situation in cities and the impact of each element on the rest of the elements. In addition, we must focus on the most important elements that contribute to the high rates of emigration to these cities and housing on the outskirts of these cities as the composition of random refocusing lacked most of the infrastructure and services, education, and health (Bisello, A, et al. ,2016). 
There is a need for regional planning to contribute to the formulation of an industrial map for the Egyptian cities in general and the agricultural hinterland in particular. Additionally, there is an absence of a mechanism to provide urban extensions resulting from endemic industries (Aly, M Sayed, 2014).

\section{References}

Al Omar, H. (2002). Introduction to The Industrial Economics. Zat Al Salasel Library, Kuwait.

Allam, A. K. (1995). Regional planning in Egypt. Anglo Library, Cairo, Egypt.

Central Agency for Public Mobilization and Statistics. (2016). Egypt Census Report 2016. Cairo, Egypt. Retrieved from http://www.capmas.gov.eg/Pages/StaticPages.aspx?page_id=5035

Egyptian Environmental Affairs Agency (EEAA). (1994). Environment Law - Cairo, Egypt. Retrieved from http://eeaa.gov.eg/en-us/laws/envlaw.aspx

General Organization for Physical Planning (GOPP). (2011). Periodical Reports of The Egyptian Urban Observatory. Cairo, Egypt. Retrieved from http://gopp.gov.eg/

General Organization for Physical Planning (GOPP). (2014). the national urban development framework in the Arab Republic of Egpt. Retrieved from http://gopp.gov.eg/wp-content/uploads/2015/01/GOPP-PA_2014.pdf

Glasgow City Council. (2011). Glasgow city vision 2061. Glasgow. Retrieved from https://www.glasgowconsult.co.uk/UploadedFiles/GCC\%202061\%20A4\%20Summary\%20Final\%20onli.p $\mathrm{df}$

Institute for Urban and Management Techniques. (2011). An analytical study of the city of Skikda, Algeria.

Institute of Design and Urban Planning (Tongji). (2014). Master planning for the city of Joshua. Shanghai, China. Retrieved from http://www.tjupdi.com/new/index.php?classid=9127

Maltese, I., Mariotti, I., \& Boscacci, F. (2016). Smart City Urban Performance and Energy. In R. Papa, \& R. Fistola (Eds.), Smart Energy in the Smart City, Green Energy and Technology. Springer International Publishing Switzerland. Retrieved from http://www.springer.com/cda/content/document/cda_downloaddocument/9783319311555-c2.pdf?SGWID= 0-0-45-1564088-p179890956

Ministry of Agriculture land protection and land reclamation. (2015). Annual Report on the Agriculture land status in Egypt. Cairo, Egypt.

Ministry of Housing, General organization for physical planning. (2013). Master plan for Kafr El Dawar city 2030. Cairo, Egypt.

Ministry of Housing, General organization for physical planning. (2014). Master plan for Kafr El Zayat city 2030. Cairo, Egypt.

Ministry of Housing, General organization for physical planning. (2014). Master plan for Hawamdeya 2030. Cairo, Egypt.

Ministry of Housing, General organization for physical planning. (2014). Master plan for Talkha city 2030. Cairo, Egypt.

Ministry of Housing, General organization for physical planning. (2015). Master plan for Deshna city 2030. Cairo, Egypt.

Papa, R., \& Fistola, R. (2016). Smart Energy in the Smart City Urban Planning for a Sustainable Future. Cham: Springer International Publishing. https://doi.org/10.1007/978-3-319-31157-9

Pugh, C. (2013). Sustainable Cities in Developing Countries. New York, Routledge.

Sayed, M. A. (2014). The Impact of Industry on The Urban growth in The Cities With Agriculture Background (Unpublished master thesis), Cairo University, Cairo, Egypt.

United Nations. (2015). The Millennium Development Goals Report. Retrieved from http://www.un.org/millenniumgoals/2015_MDG_Report/pdf/MDG\%202015\%20rev\%20(July\%201).pdf

World Bank, Annual Conference on Development Economics. (2014). Interaction between Regional and Industrial Policies, Washington USA.

Yigitcanlar, T., \& Kamruzaman, M. (2015). Planning Development and Management of Sustainable Cities, Australia, Queensland University of Technology (QUT), School of Civil Engineering and Built Environment, 
Science and Engineering Faculty, Queensland University of Technology (QUT), 2 George Street, Brisbane QLD 4001, Australia. https://doi.org/10.1016/j.habitatint.2014.06.033

Yigitcanlar, T., Dur, F., \& Dizdaroglu, D. (2015). Towards prosperous sustainable cities: a multiscalar urban sustainability assessment approach. Habitat International, 45(1), 36-46.

\section{Copyrights}

Copyright for this article is retained by the author(s), with first publication rights granted to the journal.

This is an open-access article distributed under the terms and conditions of the Creative Commons Attribution license (http://creativecommons.org/licenses/by/4.0/). 